\title{
CHANGES IN PHENOLIC PROFILE AND ANTIOXIDANT ACTIVITY OF HORSERADISH ROOTS DURING FREEZING AND FROZEN STORAGE
}

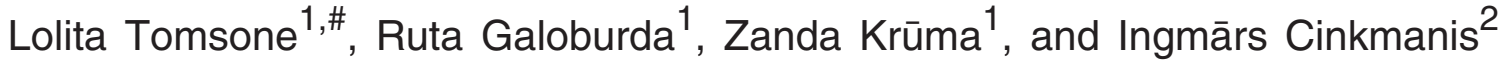 \\ ${ }^{1}$ Department of Food Technology, Latvia University of Life Sciences and Technologies, 22 Rīgas Str., Jelgava, LV-3004, LATVIA \\ 2 Department of Chemistry, Latvia University of Life Sciences and Technologies, 2 Lielā iela, Jelgava, LV-3001, LATVIA \\ \# Corresponding author, lolita.tomsone@llu.lv
}

Communicated by Tatjana Ķince

\begin{abstract}
Freezing is one of the ways to preserve plant products, because it allows inhibiting natural degradation and transformation processes of the bioactive compounds. The aim of this study was to evaluate the effect of freezing on bioactive compounds of horseradish roots and their dynamics in long-term frozen storage. Horseradish roots were frozen at two different conditions $\left(-18 \pm 2{ }^{\circ} \mathrm{C}\right.$ and $-40 \pm 2{ }^{\circ} \mathrm{C}$ ) and further stored at $-18 \pm 2{ }^{\circ} \mathrm{C}$ for 12 months. Total phenolic content (TPC), total flavonoid content (TFC), total flavonol content (TFIC), total flavan-3-ol content (TF3C), total phenolic acid content (TPAC), and radical scavenging activity (RedPow, DPPH', $A B T S^{+*}$ ) were determined spectrophotometrically. Individual phenolic compounds were deremined by liquid chromatography. The dominant individual phenolic compounds were phenolic acids (gallic and sinapic) and flavonoids (kaempferol, luteolin, and rutin). Because of freezing, TPC, TFC, and $D P P H^{\prime}$ as well as RedPow increased in horseradish roots. During storage, the content of analysed bioactive compounds mainly decreased. After 12-month storage, it was not possible to say unambiguously which of the freezing methods turned out to be better in general.
\end{abstract}

Keywords: phenolic acids, flavonoids, flavan-3-ols, scavenging activity, plate-freezing.

\section{INTRODUCTION}

Horseradish (Armoracia rusticana L.) is a perennial plant from the Brassicaceae family, which has been used as folk medicine since ancient times. Numerous studies have demonstrated that they possess antimicrobial, chemopreventive, gastroprotective, and anti-inflammatory activities (Herz et al., 2017), which justify the traditional applications. Horseradish is also used as a condiment in many traditional dishes due to its intense pungent smell. These applications could be linked to the richness of this plant in phytochemicals such as polyphenols (Herz et al., 2017). During storage and processing, many active compounds are degraded and various breakdown products are formed as a result of hydrolysis or thermal degradation (Blažević et al., 2010). Therefore, it is suggested to use low-temperature storage, which could retain higher content of bioactive compounds in stored horseradish roots, inhibiting metabolic processes, sand low- ing down microbial growth and chemical reactions (Paciulli et al., 2015).

Freezing induces ice crystal formation with various size and shape, which can disrupt cell membranes leading to the release of membrane bound phytochemicals or the breakdown of complex compounds (Leong and Oey, 2012). Ice crystals are formed throughout all matrix, including cells and interlinked cell membranes, which can cause localised concentration of solutes, dislocation of water, expanding the separation between cells, and mechanical damage of cells (Chassagne-Berces et al., 2010). Leong and Oey (2012) noted that the rate of freezing influences ice crystal formation. When product was rapidly frozen, large amounts of smaller crystals formed and caused lesser degree of cell structure disruption compared to slowly frozen product, which formed large intercellular ice crystals. According to Kyureghian et al. (2010), numerous studies showed the ef- 
fect of freezing and storage on major nutrients of fruits and vegetables, but further studies are required using modern analytical tools. Many factors contribute to frozen vegetable quality, which include but are not limited to the initial quality of product, pre-treatments, processing and storage conditions.

However, not always the cell disruption and the breakdown of complex compounds should be considered as an adverse effect. When bioactive compounds are released from cell membranes, horseradish juice richer in simple natural bioactives is obtained, thus eliminating a need for the additional technological processes. Horseradish juice may be used in food products as a natural source of antioxidants, because its phenolic compounds posess antioxidant activity (Naczk and Shahidi, 2006; Tomsone et al., 2020a).

There have been relatively few studies related to changes in chemical composition of biologically active compounds in horseradish roots caused by freezing and subsequent frozen storage. Therefore, this study aimed to evaluate the effect of freezing on bioactive compounds of horseradish roots and their dynamics in long-term frozen storage. The content of phenolic compounds and antioxidant activity were studied as important quality attributes of horseradish roots.

\section{MATERIALS AND METHODS}

Materials. Fresh horseradish roots (Armoracia rusticana L.) were collected in Sigulda, Latvia ("Keipāni”" farm), in November 2017. The horseradish roots were washed under running water and then placed on a moisture-absorbing surface for two hours. Remains of leaves and hair-like roots (small roots less than $0.5 \mathrm{~cm}$ in diameter) were removed. The roots were cut into $5 \mathrm{~cm}$ long pieces and packaged in the hermetically sealed polypropylene (PP) bags, $0.5 \mathrm{~kg}$ each. In this case, the barrier properties of the packaging material are not significant, because it is also intended for storage at reduced temperatures. In total, six packages per freezing type were prepared.

Freezing and storage. The samples were frozen according to the following procedures:

a) conventional freezing at $-18 \pm 2{ }^{\circ} \mathrm{C}$ in a freezer LUT5NF28U0 (Electrolux, EEC) (the packaged samples were placed in a freezer at $-18 \pm 2{ }^{\circ} \mathrm{C}$, the samples were completely frozen after approximately $8 \mathrm{~h}$ );

b) freezing in a FT34MkII contact plate freezer (Armfield Ltd., UK) at $-40 \pm 2{ }^{\circ} \mathrm{C}$ (the pouches with horseradish roots were placed between two pre-cooled plates at -40 $\pm 2{ }^{\circ} \mathrm{C}$, and frozen within $25 \pm 1$ min until the temperature, measured by a type $\mathrm{K}$ thermocouple inserted in the sample, reached $-18 \pm 2{ }^{\circ} \mathrm{C}$, and then the frozen samples were transferred into a freezer for storage).

All samples were stored at $-18 \pm 2{ }^{\circ} \mathrm{C}$ until further analyses. Samples were analysed on the next day after freezing (further - before storage) and after 12-month storage (further - after storage). In the study, the dynamics of biologically active compounds and radical scavenging activities in the fresh and frozen horseradish rootswere compared.

Analytical methods. The chemicals for analyses were purchased from Sigma-Aldrich (Switzerland) and Acros Organic (USA).

For all samples, the moisture content was determined in triplicate according to the standard AOAC 984.25. Moisture content was calculated and used only to express the result on dry basis.

For all spectrophotometric analyses, the extracts were obtained according to the procedure described by Tomsone $e t$ al. (2020b). Quantification was done using a JENWAY 6300 spectrophotometer (Baroworld Scientified Ltd., UK) and details of the procedure are summarised in Table 1.

For the analysis of individual phenols, ground and homogenised samples were extracted with $1 \mathrm{~N} \mathrm{HCl} / \mathrm{ET} / \mathrm{H}_{2} \mathrm{O}$ $(1 / 80 / 19 \mathrm{v} / \mathrm{v} / \mathrm{v})$ using a magnetic stirrer (magnet $4.0 \times 0.5$ $\mathrm{cm})$ at $700 \mathrm{rpm}$ for $1 \mathrm{~h}$ at room temperature $\left(20 \pm 1{ }^{\circ} \mathrm{C}\right)$. The extracts were then filtered (paper no. 89). The analyses were carried out using a liquid chromatograph LC - 20AD (Shimadzu, USA) with an analytical column C18 and photo diode array detector SPD M20A (Shimadzu, Japan). The procedure details are the same as described by Tomsone et al. (2020b).

Statistical analysis. Experimental results are means of nine parallel measurements (three packages per treatment and three repetitions per package) and were analysed by Micro-

Table 1. Brief summary of methods aplied in spectrophotometric analysis

\begin{tabular}{|c|c|c|c|}
\hline Parameter & Wavelength & Measurement units* & Reference \\
\hline Total phenolic content (TPC) & $765 \mathrm{~nm}$ & Gallic acid equivalents (GAE) & Singleton et al., 1999 \\
\hline Total flavonoid content (TFC) & $415 \mathrm{~nm}$ & Catehin equivalents (CE) & Kim et al., 2003 \\
\hline Total flavan-3-ol content (TF3C) & $500 \mathrm{~nm}$ & Catehin equivalents (CE) & Zam et al., 2012 \\
\hline Total phenolic acid content (TPAC) & $490 \mathrm{~nm}$ & Caffeic acid equivalents (CAE) & Gawlik-Dziki, 2012 \\
\hline Total flavonols content (TFlC) & $440 \mathrm{~nm}$ & Rutin equivalents (RE) & Ložiene et al., 2007 \\
\hline DPPH' radical-scavenging activity & $517 \mathrm{~nm}$ & Trolox equivalents (TE) & Yu et al., 2003 \\
\hline $\mathrm{ABTS}^{\prime+}$ radical scavenging activity & $743 \mathrm{~nm}$ & Trolox equivalents (TE) & Re et al., 1999 \\
\hline
\end{tabular}

*All data are expressed per $100 \mathrm{~g}$ dry weight (DW) 
Table 2. Changes in the phenolic class profiles depending on freezing method and after 12-month frozen storage

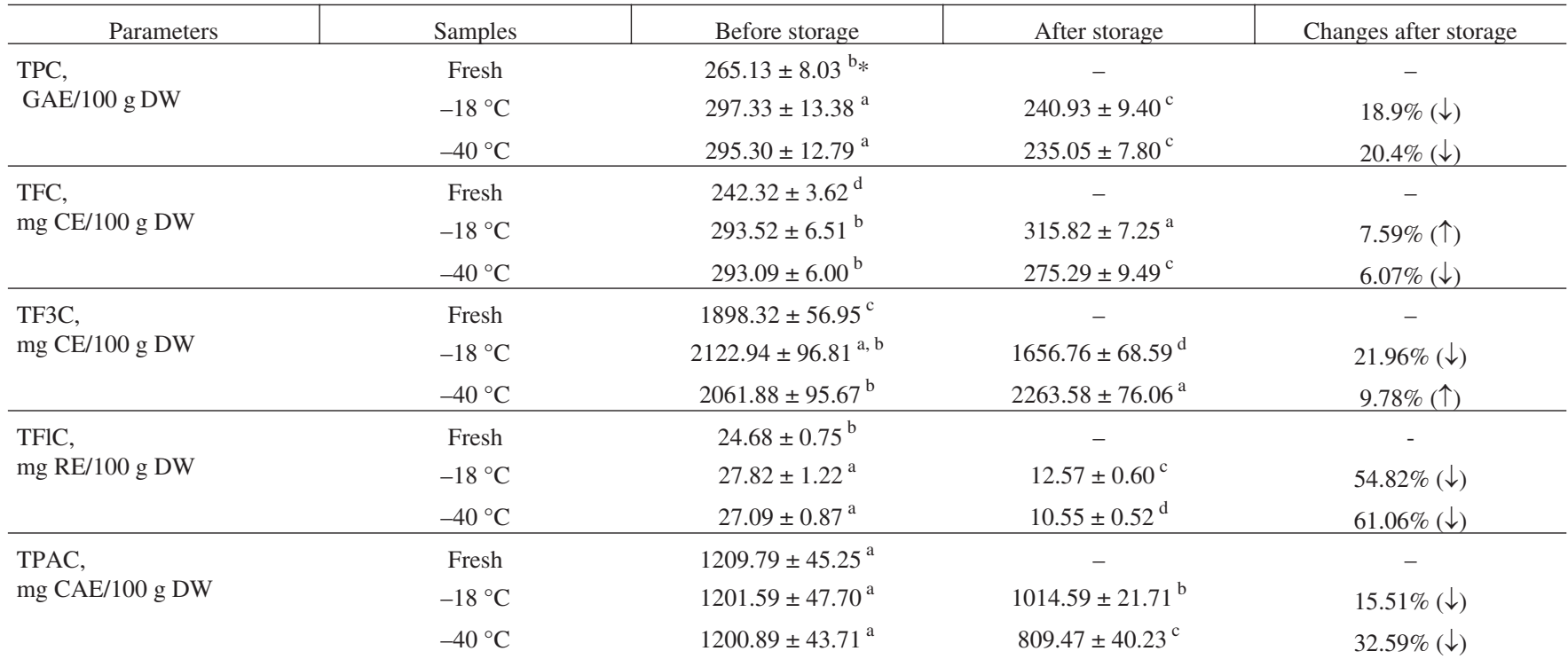

All data are means \pm standard deviation $(n=9) .{ }^{\text {a, }}, \mathrm{c} \ldots-$ values with different lowercase superscripts for the same parameter are significantly different $(p \leq$ $0.05)$.

soft Excel 2010 and SPSS 17.00. Analysis of variance (ANOVA) and the Tukey's test were used to determine differences among samples $(p<0.05)$.

\section{RESULTS}

Evaluation of the freezing effect on bioactive compounds and antioxidant activity in horseradish roots. Upon freezing, the content of almost all groups of phenolic compounds increased (Table 2) compared to their content in fresh product - TPC by $11-12 \%$, TFC by $21 \%$, flavan-3ols by $9-12 \%$, flavonols by $10-13 \%$, except total phenolic acids did not change significantly $(p>0.05)$ due to freezing.

When evaluating the changes of some flavonoids upon freezing, it was observed that catechin hydrate and rutin content increased under the reduced temperature (Table 3). Negative effects of reduced temperature were observed for the other main flavonoids in horseradish roots - kaempferol and luteolin. Quercetin was detected in fresh horseradish roots $(94.32 \pm 0.99 \mathrm{mg} / 100 \mathrm{~g} \mathrm{DW})$, but it was not found in any frozen sample.

In fresh horseradish roots, gallic acid was detected in small amounts, but after freezing, when ice crystals damaged cell structures, gallic acid content increased 4 to 4.8 times. There was no significant change in the content of sinapic acid (Table 3 ). The content of caffeic acid immediately decreased in conventionally frozen roots after freezing.

Freezing had a positive effect on the activity of primary antioxidants in horseradish roots, which can be seen with the increase of RedPow after freezing by $16-36 \%$. The activity of secondary antioxidants was affected differently $\mathrm{DPPH}^{\prime}$ activity increased, whereas $\mathrm{ABTS}^{{ }^{++}}$was not significantly $(p>0.05)$ affected by freezing (Table 4$)$.
Table 3. Content of major phenolic compounds ( $\mathrm{mg} / 100 \mathrm{~g} \mathrm{DW}$ ) in horseradish roots after freezing and after 12-month frozen storage

\begin{tabular}{lc|c|c|c}
\hline $\begin{array}{c}\text { Phenolic } \\
\text { compounds }\end{array}$ & Samples & Before storage & After storage & $\begin{array}{c}\text { Changes after } \\
\text { storage }\end{array}$ \\
\hline Catechin & Fresh & $26.58 \pm 0.28^{\mathrm{d} *}$ & - & - \\
hydrate & $-18^{\circ} \mathrm{C}$ & $95.20 \pm 1.27^{\mathrm{b}}$ & $107.19 \pm 1.14^{\mathrm{a}}$ & $12.59 \%(\uparrow)$ \\
& $-40^{\circ} \mathrm{C}$ & $31.90 \pm 0.34^{\mathrm{c}}$ & ND $^{* *}$ & $100 \%(\downarrow)$ \\
\hline Rutin & Fresh & $69.91 \pm 0.74^{\mathrm{c}}$ & - & - \\
& $-18^{\circ} \mathrm{C}$ & $72.72 \pm 0.97^{\mathrm{b}}$ & $41.57 \pm 0.44^{\mathrm{d}}$ & $42.84 \%(\downarrow)$ \\
& $-40^{\circ} \mathrm{C}$ & $68.69 \pm 0.73^{\mathrm{c}}$ & $197.93 \pm 2.03^{\mathrm{a}}$ & $188.15 \%(\uparrow)$ \\
\hline Luteolin & Fresh & $228.78 \pm 2.40^{\mathrm{a}}$ & - & - \\
& $-18^{\circ} \mathrm{C}$ & $51.80 \pm 0.69^{\mathrm{c}}$ & $19.99 \pm 0.20^{\mathrm{e}}$ & $61.41 \%(\downarrow)$ \\
& $-40^{\circ} \mathrm{C}$ & $76.67 \pm 0.81^{\mathrm{b}}$ & $24.09 \pm 0.25^{\mathrm{d}}$ & $68.58 \%(\downarrow)$ \\
\hline Kaempferol & Fresh & $112.02 \pm 1.18^{\mathrm{a}}$ & - & - \\
& $-18^{\circ} \mathrm{C}$ & $54.73 \pm 0.73^{\mathrm{c}}$ & $1.95 \pm 0.02^{\mathrm{e}}$ & $96.44 \%(\downarrow)$ \\
& $-40^{\circ} \mathrm{C}$ & $87.44 \pm 0.92^{\mathrm{b}}$ & $22.58 \pm 0.23^{\mathrm{d}}$ & $74.18 \%(\downarrow)$ \\
\hline Gallic acid & Fresh & $16.08 \pm 0.19^{\mathrm{c}}$ & - & - \\
& $-18^{\circ} \mathrm{C}$ & $63.95 \pm 0.96^{\mathrm{b}}$ & $10.11 \pm 0.31^{\mathrm{d}}$ & $84.19 \%(\downarrow)$ \\
& $-40^{\circ} \mathrm{C}$ & $77.02 \pm 0.97^{\mathrm{a}}$ & $5.97 \pm 0.35^{\mathrm{e}}$ & $92.25 \%(\downarrow)$ \\
\hline Caffeic acid & Fresh & $33.79 \pm 0.74^{\mathrm{a}}$ & - & - \\
& $-18^{\circ} \mathrm{C}$ & $21.72 \pm 0.52^{\mathrm{b}}$ & $\mathrm{ND}$ & $100 \%(\downarrow)$ \\
& $-40^{\circ} \mathrm{C}$ & $33.64 \pm 0.93^{\mathrm{a}}$ & $21.63 \pm 0.73^{\mathrm{b}}$ & $35.70 \%(\downarrow)$ \\
\hline Sinapic acid & Fresh & $58.62 \pm 1.52^{\mathrm{c}}$ & - & - \\
& $-18^{\circ} \mathrm{C}$ & $60.45 \pm 1.49^{\mathrm{c}}$ & $101.13 \pm 2.22^{\mathrm{a}}$ & $67.30 \%(\uparrow)$ \\
& $-40^{\circ} \mathrm{C}$ & $58.90 \pm 1.57^{\mathrm{c}}$ & $70.98 \pm 1.62^{\mathrm{b}}$ & $20.51 \%(\uparrow)$ \\
& & & &
\end{tabular}

* All data are means \pm standard deviation $(n=9)$. ${ }^{\mathrm{a}}$ b, c $\ldots$ - values with different lowercase superscripts for the same parameter are significantly different $(p \leq 0.05)$. $* * \mathrm{ND}$, not detected.

Evaluation of frozen storage on bioactive compounds and antioxidant activity in horseradish roots. After 12month storage, TPC did not differ significantly between conventionally and plate-frozen horseradish roots. How- 
Table 4. Antioxidant activities in fresh horseradish roots and after 12-month frozen storage

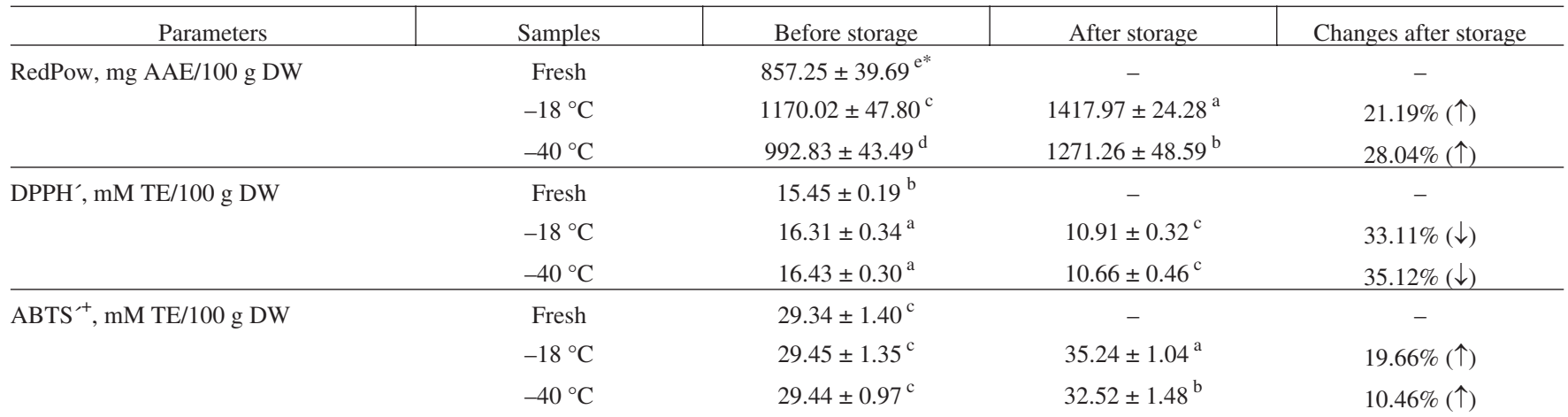

* All data are means \pm standard deviation $(n=9) .{ }^{\text {a, b }, c} \ldots$ ?- values with different lowercase superscripts for the same parameter are significantly different $(p \leq 0.05)$.

ever, their content decreased compared to the freshly frozen roots. TFlC more than halved after 12-month storage compared to the freshly frozen horseradish roots. Storage revealed a significant decrease in the TPAC and flavonoids such as kaempferol and luteolin in frozen horseradish roots. In contrast, in the plate-frozen horseradish roots, no presence of catechin hydrate was detected after storage. Platefreezing proved to be more effective for retaining of the major flavonoids other than catechin hydrate.

Content of gallic and caffeic acids was also significantly reduced after 12-month storage. Conventional freezing proved to be more effective for total phenolic acids and individual compounds, such as gallic and sinapic acid.

The antioxidant activity of $\mathrm{ABTS}^{\text {,+ }}$ cations and RedPow after 12-month storage was higher than immediately after freezing. DPPH' scavenging activity in horseradish root extracts after storage decreased.

\section{DISCUSSION}

During freezing, ice crystal formation and growth takes place in foods, which may cause cell damage (Leong and Oey, 2012). As a result, phenolic compounds are released from the cell vacuoles, which results in an increase in the content of various compounds, as observed in this study (Tables 2-4). However, interactions of phenolic compounds with other plant components, such as carbohydrates and proteins, can form complex compounds that can be quite insoluble. TPC did not differ significantly in horseradish roots frozen by any of the freezing methods used. Similar trends as for the analysed horseradish were also shown by freezing peaches at $-20{ }^{\circ} \mathrm{C}$ for $24 \mathrm{~h}$, which resulted in an increase of total phenolic content (TPC) (Oliveira et al., 2016). Similar to TPC and TFC in the freezing process of horseradish roots, the content of total flavan-3-ols increased by $10 \%$. The effect of freezing rate was an important factor in the increase of TF3C content during their freezing. Freezing had the same effect on catechin hydrate content, which also increased significantly, especially in conventionally frozen horseradish roots. However, phenolic compounds can be de- graded during freezing and frozen storage (Chaovanalikit and Wrolstad, 2004; Poiana et al., 2010). In the current study, increase of TFlC was observed after freezing. Similarly, freezing of Ample Raspberries was shown to significantly increase the content of flavonols (Mullen et al., 2002). This was more characteristic for conjugated flavonols, which after freezing were released more easily from cells into solvent. In turn, during the further biochemical reactions, free flavonols were degraded. A higher content of total flavonols was observed in the conventionally frozen horseradish roots, which indicates the importance of ice crystal size in flavonol release and therefore their extraction from matrix during analyses (Sinha et al., 2010; Alexandre et al., 2013).

The freezing did not significantly affect $(p>0.05)$ the content of total phenolic acids, which is in accordance with Liu (2004). Effect of low temperature on bioactive compounds in vegetables can differ depending on the product matrix. Dutra et al. (2017) reported that freezing of siriguela (Spondias purpurea L.), mangaba (Hancornia speciosa), and umbu-caji (Spondias spp.) fruits resulted in diverse changes in individual polyphenols. Mazzeo et al. (2015) also observed that processing contributes to increase of phenolic acids in zucchini, decrease in green beans and unchanged content in asparagus. This can be explained by the presence of phenolic compounds in plants in free forms or covalently bound with macromolecules, or packed in cellular organs or cell wall components (Palermo et al., 2014). In addition, other studies have discussed similar tendencies, where content and quality of bioactive compounds depended on many factors, including initial quality, freezing rate, storage conditions, temperature, and time (Olivera et al., 2008; Poiana et al., 2010; Mazzeo et al., 2015).

Flavonoids are one of the largest groups of phenolic compounds found in horseradish roots and are characterised by antioxidant activity (Liu, 2004). In plants, flavonoids are commonly found in epidermal cells and are found as glycoside aglycones (Sakihama et al., 2002). Glycosides in intercellular spaces are commonly located in vacuoles and apoplasts (Ku et al., 2020). Enhanced chemical extraction 
of flavonoids can be caused by freezing, long-term freezer storage, and blanching (Olivera et al., 2008). The content of kaempferol and luteolin of horseradish roots decreased immediately after freezing (Table 3). Their content decreased faster in conventionally frozen roots compared to platefrozen roots. This was in contrast to the commercial freezing of raspberries at $-30{ }^{\circ} \mathrm{C}$, where the content of kaempferol and quecetin significantly increased from $21.2 \pm$ $0.4 \mathrm{nmol} / \mathrm{g}$ (fresh berries) to $25.6 \pm 0.4$ (frozen berries) $\mathrm{nmol} / \mathrm{g}$ and from $1.1 \pm 0.07 \mathrm{nmol} / \mathrm{g}$ (fresh berries) to $1.4 \pm$ $0.03 \mathrm{nmol} / \mathrm{g}$ (frozen berries) $\mathrm{nmol} / \mathrm{g}$, respectively (Mullen et al., 2002).

Quercetin was detected rarely in fresh horseradish roots. It was not found in any of the frozen samples, most probably due to enzymatic activity and other biochemical processes occurring in the frozen product. Biochemical reactions result in the formation of rutin from quercetin $(\mathrm{Li}$ et al., 2020).

Freezing decreases the rate of biochemical, chemical and physical changes in plant based materials, but does not stop the reactions that induce complex compound breakdown or, contrary, formation of new compounds (Oliveira et al., 2016). After 12-month storage, the TPC of horseradish roots decreased significantly compared to its initial content before storage, irrespective of the freezing method used. Similar trends were observed by Puupponen-Pimiä et al. (2003) for frozen carrots. The reduction of phenolic compounds during storage may be associated with enzyme, especially polyphenol oxidase, activity (Chaovanalikit and Wrolstad, 2004; Poiana et al., 2010). Prabhu and Barrett (2009) reported an increase between 3 and 5\% in TPC of African leafy vegetables after 90 days in Cassia tora leaves, and between $8-9 \%$ in Corchorus tridens leaves. Volden et al. (2009), in a study of long-term frozen storage on cauliflower observed that TPC did not change extensively over the course of the freezer storage. However, in some cultivars, significant reductions by $7-13 \%$ were observed after 12-month storage. Chaovanalikit and Wrolstad (2004) alo reported that freezing and storage at $-18{ }^{\circ} \mathrm{C}$ for a long period (ten months) reduced the TPC of cherries and strawberries. Freezing under liquid nitrogen in Bing cherries stored at $-23{ }^{\circ} \mathrm{C}$ resulted in the degradation of phenolic compounds and decreased TPC, whereas cherries stored at $-70{ }^{\circ} \mathrm{C}$ showed relatively stable phenolic compound content (Poiana et al., 2010).

In general, the frozen storage showed a positive influence on TFC in horseradish roots (Table 2), which was also observed in asparagus, green beans and zucchini (Mazzeo et al., 2015) and Brussels sprouts (Olivera et al., 2008). Freezing conditions had significant effect $(p<0.05)$ on TFC in horseradish roots during storage. Significantly lower TFC (on average 11\% compared to the conventional freezing) was observed in the plate-frozen horseradish roots, possibly due to the formation of small ice crystals as a result of rapid freezing, causing less damage to horseradish root cells (Sinha et al., 2010; Alexandre et al., 2013), thus release of smaller amounts of flavonoid compounds isolated by cell membranes. The loss of bioactive compounds during frozen storage is mainly induced by enzymatic activity (Oliveira et $a l ., 2016)$, because freezing just slows down the rate of reactions. Freezing caused an increase of TFC in horseradish roots raised by $21 \%$, which may have been due to a disruption of the cellular matrix and more facilitated extraction of phenolics (Oliveira et al., 2016).

Kaempferol, quercetin and rutin are involved in the chain of flavonoid biosynthetic reactions (Ali et al., 2010). In conventionally frozen samples, the content of kaempferol gradually decreased in the biosynthetic reactions by conversion to quercetin and rapid synthesis to rutin, resulting in a very low content of quercetin (Li et al., 2020). The gradual decrease in rutin during storage can be explained by further biochemical reactions leading to the formation of the relevant metabolites.

The content of flavonol glycosides, such as rutin, in Bing cherries increased after freezing and during storage, regardless of the type of freezing method (temperatures both $-23{ }^{\circ} \mathrm{C}$ and $-70{ }^{\circ} \mathrm{C}$ ). Similar to horseradish roots, the rutin content increased significantly in $-70{ }^{\circ} \mathrm{C}$ frozen cherries. In fresh cherries the rutin content was $4.72 \pm 0.17 \mathrm{mg} / 100 \mathrm{~g}$. After six months of storage, the content of flavonol glycosides in $-23{ }^{\circ} \mathrm{C}$ frozen cherries was $5.20 \pm 0.55$, and in $-70{ }^{\circ} \mathrm{C}$ frozen cherries $-6.04 \pm 0.65 \mathrm{mg}$ rutin/100 $\mathrm{g}$ (Chaovanalikit and Wrolstad, 2004). In contrast, the rutin content of conventionally frozen horseradish roots decreased significantly after 12 months of storage.

Both studied freezing methods indicated significant differences $(p<0.05)$ in the TF3C and TFlC throughout the frozen storage. TFlC more than halved (compared to baseline) after storage, which might be due to the biochemical reactions causing a breakdown of flavonols and formation of other compounds such as flavanols. In the flavonoid biosynthesis pathway, flavanonols are further converted to flavonols, flavandiols, flavanols, and endiols (Belitz et al., 2009). The decrease in TFlC can be explained by a slower rate of formation of new flavonoids than the conversion of existing flavonoids to other classes / groups of organic compounds.

After 12-month storage, caffeic acid in conventionally frozen horseradish roots was not detected but in the platefrozen $\left(-40{ }^{\circ} \mathrm{C}\right)$ roots it substantially decreased. In contrast to content of caffeic acid, the sinapic acid content of horseradish roots increased with storage time irrespective of freezing method. However, a higher increase in the sinapic acid content was observed in conventionally frozen roots, probably due to larger ice crystals formed in the freezing process. Caffeic acid and sinapic acid are mainly found in bound form via ester bonds, with cell wall structural components such as cellulose, lignin, and protein (Liu, 2004).

In a sequential biosynthesis, caffeic acid is further synthesised to ferullic acid, then hydroxyferullic acid, and finally sinapic acid (Ali et al., 2010), which can explain the decrease in caffeic acid and significant increase in sinapic 
acid. In addition, the content of caffeic acid in conventionally frozen roots decreased faster during storage, while the content of sinapic acid increased faster. In turn, the caffeic acid content decreased more slowly in the plate-frozen samples, and hence the sinapic acid content increased more slowly.

During frozen storage, due to biochemical processes, gallic acid content rapidly decreased. Immediately after freezing, the gallic acid content of horseradish roots increased significantly. Gallic acid belongs to the hydroxybenzoic acids group. Subsequent biochemical transformations result in the formation of salicylic acid, p(4)-hydroxybenzoic acid, gallic acid and other benzoic acid derivatives (Ali et al., 2010). Gallic acid is further transformed into its derivatives, which do not belong to the group of phenolic acids, and hence the content of any other individual phenolic acid did not increase.

Antioxidant activity (DPPH') of horseradish roots decreased after 12-month storage (Table 4). Olivera and colleagues (Olivera et al., 2008) also observed a decrease in the DPPH radical scavenging activity of Brussels sprouts frozen at $-18{ }^{\circ} \mathrm{C}$ and stored for eight months. For frozen cauliflowers, DPPH' decreased during storage, with this decrease being faster in samples frozen at $-20^{\circ} \mathrm{C}$, compared the samples frozen at $-30{ }^{\circ} \mathrm{C}$ (Gebczyński and Kmiecik, 2006). No significant effect of the horseradish root freezing method $(p<0.05)$ was observerd during storage.

In contrast, antioxidant activity $\left(\mathrm{ABTS}^{-+}\right)$and RedPow increased after storage of horseradish roots. Studies by other scientists revealed various changes in antioxidant activity under due to reduced temperature. For example, when peaches are frozen at $-20{ }^{\circ} \mathrm{C}$ for $24 \mathrm{~h}$, total antioxidant activity increased slightly (Oliveira et al., 2016). In contrast, the antioxidant activity of Ample Raspberries measured by electronspin resonance increased after freezing (Mullen et al., 2002).

A group of Romanian scientists who studied the effects of low temperatures on raspberry, blueberry and blackberry found a gradual decrease in RedPow over ten months of storage (Poiana et al., 2010).

\section{CONCLUSION}

In general, freezing had a positive effect on content of biologically active compounds in horseradish roots, irrespective of freezing method. Immediately after freezing, the content of phenolic compounds and antioxidant activities increased. Despite the fact that in many studies fast freezing (in our case plate-freezing) has been better, conventional freezing had similar efficiency in horseradish root processing. However, for preservation of kaempferol, luteolin, gallic acid and caffeic acid during freezing, it is better to select plate-freezing.

After 12-month storage, it was not possible to conclude unambiguously which of the freezing methods was better in general. Plate-freezing was better for preservation of content of rutin, luteolin, kaempferol, and caffeic acid, while conventional freezing was better for preservation of content of catechin hydrate, gallic acid, and sinapic acid and antioxidant activity in horseradish roots during long-term storage.

\section{ACKNOWLEDGEMENTS}

This study was financially supported by the ERDF Postdoctoral Research Support Programme (project Nr.1.1.1.2/16///001) grant number Nr.1.1.1.2./VIAA/1/16/ 187.

\section{REFERENCES}

Alexandre, E. M. C., Brandao, T. R. S., Silva, C. L. M. (2013). Frozen food and technology. In: Visakh, P. M., Thomas, S., Iturriaga, L. A., Ribotta, P. D. (eds.). Advances in Food Science and Technology. Scrivener Publishing LLC, Beverly, MA, pp. 123-150.

Ali, K., Maltese, F., Choi, Y. H., Verpoorte, R. (2010). Metabolic constituents of grapevine and grape-derived products. Phytochem. Rev., 9, $357-378$.

AOAC 984.25 Quick frozen French fried potatoes, Moisture, Gravimetry (convection oven). http://www.aoacofficialmethod.org/index.php? main_page $=$ product_info\&cPath $=1 \&$ products_id=1170 (accessed 12.01.2022).

Athukorala, Y., Kim, K. N., Jeon, Y. J. (2006). Antiproliferative and antioxidant properties of an enzymatic hydrolysate from brown alga, Ecklonia cava. Food Chem. Toxicol., 44, 1065-1074.

Belitz, H. D., Grosch, W., Schieberle, P. (2009). Food Chemistry. Springer, Berlin, Heidelberg. 1070 pp.

Blažević, I., Radonić, A., Mastelić, J., Zekić, M., Skočibušić, M., Maravić, A. (2010). Glucosinolates, glycosidically bound volatiles and antimicrobial activity of Aurinia sinuata (Brassicaceae). Food Chem., 121 (4), 1020-1028.

Chaovanalikit, A., Wrolstad, R. E. (2004). Anthocyanin and polyphenolic composition of fresh and processed cherries. J. Food Sci., 69, 1-13.

Chassagne-Berces, S., Fonseca, F., Citeau, M., Marin, M. (2010). Freezing protocol effect on quality properties of fruit tissue according to the fruit, the variety and the stage of maturity. LWT - Food Sci. Technol., 43, 1441-1449.

Dutra, R. L. T., Dantas, A. M., Marques, D. de A., Batista, J. D. F., Meireles, B. R. L. de A., de Magalhães Cordeiro, Â. M. T., Magnani, M., Borges, G. da S. C. (2017). Bioaccessibility and antioxidant activity of phenolic compounds in frozen pulps of Brazilian exotic fruits exposed to simulated gastrointestinal conditions. Food Res. Int., 100, 650-657.

Gawlik-Dziki, U. (2012). Dietary spices as a natural effectors of lipoxygenase, xanthine oxidase, peroxidase and antioxidant agents. LWT - Food Sci. Technol., 47, 138-146.

Gebczyński, P., Kmiecik, W. (2006). Effects of traditional and modified technology, in the production of frozen cauliflower, on the contents of selected antioxidative compounds. Food Chem., 101, 229-235.

Herz, C., Tran, H. T. T., Marton, M.-R., Maul, R., Baldermann, S., Schreiner, M., Lamy, E. (2017). Evaluation of an aqueous extract from horseradish root (Armoracia rusticana Radix) against lipopolysaccharide-induced cellular inflammation reaction. Evidence-Based Complement. Altern. Med., 2017, 1950692.

Kim, D. O., Jeong, S. W., Lee, C. Y. (2003). Antioxidant capacity of phenolic phytochemicals from various cultivars of plums. Food Chem., 81, 321-326.

Ku, Y. S., Ng, M. S., Cheng, S. S., Lo, A. W. Y., Xiao, Z., Shin, T. S., Chung, G., Lam, H. M. (2020). Understanding the composition, biosynthesis, accumulation and transport of flavonoids in crops for the promotion of crops 
as healthy sources of flavonoids for human consumption. Nutrients, 12 (6), $1-23$.

Kyureghian, G., Stratton, J., Bianchini, A., Albrecht, J. (2010). Nutritional comparison of frozen and non-frozen fruits and vegetables: Literature review. Food Processing Centre. University of Nebraska-Lincoln, 48 pp. https://citeseerx.ist.psu.edu/viewdoc/download?doi=10.1.1.1058.7754\& rep=rep1\&ype=pdf (accessed 15.12.2021).

Leong, S. Y., Oey, I. (2012). Effects of processing on anthocyanins, carotenoids and vitamin $\mathrm{C}$ in summer fruits and vegetables. Food Chem., 133, $1577-1587$.

Li, X., Wu, Z., Xiao, S., Wang, A., Hua, X., Yu, Q., Liu, Y., Peng, L., Yang, Y., Wang, J. (2020). Characterization of abscisic acid (ABA) receptors and analysis of genes that regulate rutin biosynthesis in response to ABA in Fagopyrum tataricum. Plant Physiol. Biochem., 157, 432-440.

Liu, R. H. (2004). Potential synergy of phytochemicals in cancer prevention: mechanism of action. J. Nutr., Supplement, 3479S-3485S

Ložiene, K., Venskutonis, P. R., Šipailiene, A., Labokas, J. (2007). Radical scavenging and antibacterial properties of the extracts from different Thymus pulegioides L. chemotypes. Food Chem., 103, 546-559.

Mazzeo, T., Paciulli, M., Chiavaro, E., Visconti, A., Fogliano, V., Ganino, T., Pellegrini, N. (2015). Impact of the industrial freezing process on selected vegetables. Part II. Colour and bioactive compounds. Food Res. Int., 75, 89-97.

Mullen, W., Stewart, A. J., Lean, M. E. J., Gardner, P., Duthie, G. G., Crozier, A. (2002). Effect of freezing and storage on the phenolics, ellagitannins, flavonoids, and antioxidant capacity of red raspberries. $J$. Agric. Food Chem., 50, 5197-5201.

Naczk, M., Shahidi, F. (2006). Phenolics in cereals, fruits and vegetables: Occurrence, extraction and analysis. J. Pharm. Biomed. Anal., 41 (5), 1523-1542.

Oliveira, A., Alexandre, E. M. C., Coelho, M., Barros, R. M., Almeida, D. P. F., Pintado, M. (2016). Peach polyphenol and carotenoid content as affected by frozen storage and pasteurization. LWT - Food Sci. Technol., 66, 361-368.

Olivera, D. F., Vińa, S. Z., Marani, C. M., Ferreyra, R. M., Mugridge, A., Chaves, A. R., Mascheroni, R. H. (2008). Effect of blanching on the quality of Brussels sprouts (Brassica oleracea L. gemmifera DC) after frozen storage. J. Food Eng., 84, 148-155.

Paciulli, M., Ganino, T., Pellegrini, N., Rinaldi, M., Zaupa, M., Fabbri, A., Chiavaro, E. (2015). Impact of the industrial freezing process on selected vegetables. Part I. Structure, texture and antioxidant capacity. Food Res. Int., 75, 89-97.

Palermo, M., Pellegrini, N., Fogliano, V. (2014). The effect of cooking on the phytochemical content of vegetables. J. Sci. Food Agric., 94, 1057-1070.
Poiana, M. A., Moigradean, D., Raba, D., Alda, L. M., Popa, M. (2010). The effect of long-term frozen storage on the nutraceutical compounds, antioxidant properties and color indices of different kinds of berries. J. Food, Agric. Environ., 8, 54-58.

Puupponen-Pimiä, R., Häkkinen, S. T., Aarni, M., Suortti, T., Lampi, A. M., Eurola, M., Piironen, V., Nuutila, A. M., Oksman-Caldentey, K. M. (2003). Blanching and long-term freezing affect various bioactive compounds of vegetables in different ways. J. Sci. Food Agric., 83, 1389-1402.

Re, R., Pellegrini, N., Proteggente, A., Pannala, A., Yang, M., Rice-Evans, C. (1999). Antioxidant activity applying an improved ABTS radical cation decolorization assay. Free Radic. Biol. Med., 26, 1231-1237.

Sakihama, Y., Cohen, M. F., Grace, S. C., Yamasaki, H. (2002). Plant phenolic antioxidant and prooxidant activities: Phenolics-induced oxidative damage mediated by metals in plants. Toxicology, 177 (1), 67-80.

Singleton, V. L., Orthofer, R., Lamuela-Raventós, R. M. B. T. (1999). Analysis of total phenols and other oxidation substrates and antioxidants by means of Folin-ciocalteu reagent. In: Oxidants and Antioxidants. Part A. Vol. 299. Academic Press, pp. 152-178.

Sinha, N., Hui, Y. H., Evranuz, E. Ö., Siddiq, M., Ahmed, J. (2010). Handbook of Vegetables and Vegetable Processing. Wiley-Blackwell, Ames, Iowa. $772 \mathrm{pp}$.

Sitthitrai, K., Ketthaisong, D., Lertrat, K., Tangwongchai, R. (2015). Bioactive, antioxidant and enzyme activity changes in frozen, cooked, mini, super-sweet corn (Zea mays L. saccharata 'Naulthong'). J. Food Compos. Anal., 44, 1-9.

Tomsone, L., Galoburda, R., Kruma, Z., Cinkmanis, I. (2020b). Characterization of dried horseradish leaves pomace: Phenolic compounds profile and antioxidant capacity, content of organic acids, pigments and volatile compounds. Eur. Food Res. Technol., 246 (8), 1647-1660.

Tomsone, L., Galoburda, R., Kruma, Z., Majore, K. (2020a). Physicochemical properties of biscuits enriched with horseradish (Armoracia rusticana L.) products and bioaccessibility of phenolic after simulated human digestion. Polish J. Food Nutr. Sci., 70 (4), 419-428.

Volden, J., Bengtsson, G. B., Wicklund, T. (2009). Glucosinolates, 1-ascorbic acid, total phenols, anthocyanins, antioxidant capacities and colour in cauliflower (Brassica oleracea L. ssp. botrytis); effects of long-term freezer storage. Food Chem., 112, 967-976.

Yu, L., Perret, J., Harris, M., Wilson, J., Haley, S. (2003). Antioxidant properties of bran extracts from 'Akron' wheat grown at different locations. $J$. Agric. Food Chem., 51 (6), 1566-1570.

Zam, W., Bashour, G., Abdelwahed, W., Khayata, W. (2012). Separation and purification of proanthocyanidins extracted from pomegranate's peels (Punica granatum). Int. J. Pharm. Sci. Nanotechnol., 5 (3), 1808-1813.

Received 22 March 2021

Accepted in the final form 17 November 2021

\section{MĀRRUTKU SAKN̦U FENOLU PROFILA UN ANTIOKSIDANTU AKTIVITĀTES IZMAIṆAS, SASALDĒJOT UN UZGLABĀJOT SASALDĒTĀ VEIDĀ}

Saldēšana ir viens no vienkāršākajiem augu valsts produktu uzglabāšanas veidiem. Sasaldējot ir iespējams kavēt bioaktīvo savienojumu dabiskos noārdīšanās un pārveidošanās procesus. Šì pētījuma mērḳis bija izpētīt bioaktīvo savienojumu un antioksidantu aktivitātes izmainas, dažādi sasaldējot un uzglabājot saldētavā mārrutku saknes. Kā kontrole tika analizētas svaigas mārrutku saknes. Mārrutku saknes tika sasaldētas divos dažādos veidos $\left(-18 \pm 2{ }^{\circ} \mathrm{C}\right.$ un $\left.-40 \pm 2{ }^{\circ} \mathrm{C}\right)$, un tālāk uzglabātas $-18 \pm 2{ }^{\circ} \mathrm{C}$. Spektrofotometriski tika noteikts kopējo fenolu saturs (TPC), kopējo flavonoīdu saturs (TFC), kopējo flavonolu saturs (TFlC), kopējo flavan-3-olu saturs (TF3C), kopējais fenolskābju saturs (TPAC), antioksidantu aktivitāte $\left(\mathrm{DPPH}^{\prime}, \mathrm{ABTS}^{++}\right)$un reducēšanas spēja (RP). Atsevišķu fenolu savienojumu noteikšanai tika izmantota šķidruma hromatogrāfija. Dominējošie individuālie fenolu savienojumi ir fenolskābes (gallulskābe un sinapīnskābe) un flavonoīdi (kaempferols, luteolīns un rutīns). Sasaldēšanas rezultātā mārrutku saknēs palielinājās TPC, TFC, TF3C, DPPH', kā arī RedPow. Neraugoties uz to, ka daudzos pētījumos ātrsaldēšana ir bijusi labāka, apstrādājot mārrutku saknes, abas saldēšanas metodes bija līdzvērtīgas. Uzglabāšanas laikā praktiski visu analizēto bioaktīvo savienojumu saturs saknēs samazinājās. Arī pēc uzglabāšanas 12 mēnešiem nevar viennozīmīgi nosaukt labāko saldēšanas metodi mārrutku sakṇu bioloǵiski aktīvo savienojumu saglabāšanai. 